\title{
Newly Synthesized Catalytic and Regulatory Components of Adenylate Cyclase Are Expressed in Neurites of Cultured Sympathetic Neurons
}

\author{
Aviva M. Tolkovsky \\ Department of Biochemistry, Cambridge University, Cambridge CB2 1QW, United Kingdom
}

\begin{abstract}
Forskolin- and guanine nucleotide-stimulated adenylate cyclase activities were measured in microdissected sections of neurites from small explants and in dispersed cell cultures of sympathetic ganglion neurons to determine whether a competent system for regulated formation of cAMP, consisting of both catalytic units of adenylate cyclase and regulatory GTP binding proteins, is synthesized during neurite outgrowth and where it is distributed in the neuron. An increase in both guanine nucleotide- and forskolin-dependent activity of adenylate cyclase occurred concomitantly with neurite outgrowth and was directly proportional to neurite length. Separate analysis of adenylate cyclase activity in explant cell bodies or neurites showed that the increased activity was localized entirely in the neurites, while activity in the cell bodies remained virtually constant during growth. Concentric sections of neurites of $\sim 500 \mu \mathrm{m}$ width, which contained similar volumes of neurites as determined with the indicator BCECF (Rink et al., 1982), produced similar levels of CAMP, indicating an even distribution of adenylate cyclase in the neurites. Cell bodies, when stimulated by GTP $\gamma \mathrm{S}$, produced $236 \pm 46$ attomol cAMP/min $\left(30^{\circ} \mathrm{C}\right) /$ cell body and an additional $52.6 \pm 20$ attomol $\mathrm{CAMP} / \mathrm{min}\left(30^{\circ} \mathrm{C}\right) /$ neuron were produced with each day of neurite growth $(\sim 400$ $\mu \mathrm{m})$. Assuming a turnover number of $2000 \mathrm{~min}^{-1}$, cell bodies and neurites were calculated to contain similar densities of catalytic unit molecules on their surface (9-28 molecules/ $\left.\mu \mathrm{m}^{2}\right)$. An abundant GTP binding protein, detected by ADPribosylation with pertussis toxin, was also widely distributed in the neuron. A competent adenylate cyclase system thus appears to be a constitutive component of neurite membranes.
\end{abstract}

The phosphorylated state of several proteins of diverse function and localization in invertebrate and vertebrate neurons is altered by activation of specific protein kinases (Nairn et al., 1985). It

\footnotetext{
Received Jan. 7, 1986; revised Apr. 11, 1986; accepted Apr. 24, 1986.

This work was supported by a senior research fellowship from Amersham International, held at Christ's College, Cambridge. I wish to thank Dr. M. Noble and Dr. R. Keynes for their critical reading of earlier versions of the manuscript, Dr. C. M. Bate for suggesting the possibility that a fluorescent dye might provide a measure of neurite volume, Dr. G. A. Smith for synthesizing and providing the acetoxymethyl ester of BCECF, and Dr. J. C. Metcalfe for his valuable criticism and help.

Correspondence should be addressed to Aviva M. Tolkovsky, Department of Biochemistry, Cambridge University, Tennis Court Road, Cambridge CB2 1QW, U.K.

Copyright (C) 1987 Society for Neuroscience $0270-6474 / 87 / 010110-10 \$ 02.00 / 0$
}

has therefore been postulated that phosphorylation reactions, exemplified by cAMP-dependent protein phosphorylation of $\mathrm{K}^{+}$ channels in molluscan neurons (Kandel et al., 1983; Novak Hofer et al., 1985), are important regulatory mechanisms for modifying the properties of neurons. cAMP and calcium-dependent protein phosphorylation may also be involved in regulating neurotransmitter synthesis in cultured sympathetic neurons during devclopment (Walicke and Patterson, 1981). For a critical assessment of any role for cAMP in regulating development and function of mammalian neurons, it must first be demonstrated that (1) developing neurons can synthesize cAMP, e.g., express adenylate cyclase (AC); (2) cAMP levels in the cell are sufficient to activate protein kinases; (3) such activated protein kinase causes protein phosphorylation. This study examines the first of these questions by analyzing at what stage of development of cultured sympathetic neurons the catalytic unit of $A C$ and its associated regulatory GTP binding proteins are synthesized and where these proteins are located in the neuron.

Recently, it has been demonstrated that cAMP and $\mathrm{Ca}^{2+}$ dependent phosphorylation, as well as cAMP binding proteins, occurs in "growth cone particles" isolated from fetal rat brain (Ellis et al., 1985; Katz et al., 1985). From the early and wide distribution of neuronal substrates for cAMP-dependent protein kinase, and the rapid metabolism of cAMP, which would prevent cAMP diffusion over large distances, it might thus be expected that $\mathrm{AC}$ is also synthesized and distributed throughout the neuronal plasma membrane early in development if cAMP is involved in regulating developmental patterns of neurons. Little is known, however, about the mechanisms that control the synthesis and distribution of $\mathrm{AC}$ in developing or mature neurons, although experiments with synaptosomal preparations suggest that at least nerve terminals contain AC activity (Dunwiddie and Hoffer, 1982; Mulder and Schoffelmeer, 1985; Schoffelmeer et al., 1985). Furthermore, it has not been established whether GTP binding proteins, which are necessary in all cells for the modulation of AC activity by receptors for hormones and neurotransmitters, are functional during early development.

For unequivocal localization of functional AC and GTP binding proteins in neurites, both forskolin- and guanine nucleotidestimulated $\mathrm{AC}$ activities were measured in pure neurite populations microdissected out of explant cultures of rat superior cervical ganglion (SCG). Dispersed cell cultures were used to quantitate the density of AC and GTP binding proteins. It is shown that a guanine nucleotide-responsive $\mathrm{AC}$ system is expressed throughout the sympathetic neuron from the earliest stages of growth. 


\section{Materials and Methods}

Cell preparation and growth media. SCG from newborn rats (1-2 d postnatal) were excised initially into enriched L15 (Gibco) plating medium (prepared as described by Hawrot and Patterson, 1979) without added glucose. Ganglia were desheathed and transferred to final plating medium containing $50 \mu \mathrm{l} / \mathrm{ml} 30 \%$ glucose ( $0.75 \%$ final concentration). Ganglia could be stored in this medium at $4^{\circ} \mathrm{C}$ for up to a week without apparent loss of the potential to regenerate neurites, but ganglia were normally used immediately or within $12 \mathrm{hr}$ after excision. Preparation of explant cultures was similar to the method of Estridge and Bunge (1978). Ganglia were removed one by one onto the inside of a $3 \mathrm{~cm}$ plastic petri dish cover and cut into 6-8 pieces of $200-400 \mu$ m diameter using a sterile 23 surgical blade. Segments from 10-20 ganglia were pooled and 5-6 pieces were placed in $3 \mathrm{~cm}$ petri dishes precoated with collagen containing $0.5 \mathrm{ml}$ preheated growth medium (see below), leaving $\sim 1 \mathrm{~cm}$ between any 2 explants. The small amount of medium ensured that explants remain as placed until attachment, which was complete in 2-3 hr. Growth medium, $1 \mathrm{ml}$, was added after $12 \mathrm{hr}$, and medium was changed every $3 \mathrm{~d}$. Growth medium consisted of L15$\mathrm{CO}_{2}$ enriched with glucose, glutamine, vitamins, and antibiotics as described by Hawrot and Patterson (1979), $5 \%$ rat serum (prepared sterile from adult rats deprived of solid food overnight), $10 \mu \mathrm{M}$ cytosine-1- $\beta$ D-arabinoside (Sigma Chemical Co.), stored at $-20^{\circ} \mathrm{C}$ as 100 -fold concentrate, and $800 \mathrm{ng} / \mathrm{ml}$ purified $2.5 \mathrm{~S} \mathrm{NGF}$, prepared by the rapid method described by Mobley et al. (1976) and stored as a 133-fold concentrate in $150 \mu \mathrm{l}$ lots at $-20^{\circ} \mathrm{C}$. Single-cell suspensions were prepared by mechanical dissociation (Hawrot and Patterson, 1979). Cells were teased out of 6-10 ganglia into $200 \mu$ l of L15-air plating medium using forceps and titurated 3 times in a pulled glass capillary (internal diameter $\sim 100 \mu \mathrm{m}$ ) to form a suspension of mostly single cells. Cells that remained in suspension 5 min after final tituration were added in $10 \mu \mathrm{l}$ drops into a well formed by adhesion of a sterile ring of $1 \mathrm{~cm}$ diameter, cut from the wide end of the plastic disposable tip used with a $1 \mathrm{ml}$ micropipette, to a collagen-coated $3 \mathrm{~cm}$ petri dish containing 1.5 $\mathrm{ml} \mathrm{L15}-\mathrm{CO}_{2}$ growth medium. Yield of viable neurons was quite low $(\sim 10 \%)$, but very few non-neuronal cells were observed at plating.

Collagen preparation. Collagen preparation was modified from the method of Bornstein (1958). Sterile tendons from 2 rat tails (150-180 g rats) were dissolved in $25 \mathrm{ml}$ sterile $3 \mathrm{~mm}$ acetic acid at $4^{\circ} \mathrm{C}$ by stirring for $12 \mathrm{hr}$. Solution was diluted to $100 \mathrm{ml}$, centrifuged for $30 \mathrm{~min}$ at $25,000 \times \mathrm{g}$, and the clear supernatant was further diluted to give 0.3 O.D. at $280 \mathrm{~nm}$. Culture dishes ( $3 \mathrm{~cm}$ diameter) were coated with 200 $\mu \mathrm{l}$ of this collagen solution, opened, and air-dried in a laminar-flow cabinet for 30-45 min. L15- $\mathrm{CO}_{2}$ growth medium was added immediately, and dishes were placed in an incubator containing $5 \% \mathrm{CO}_{2}$ and $100 \%$ humidity until just prior to plating.

Enzyme assays. Cultures were washed 3 times in L15-air leaving $\sim 500 \mu \mathrm{l}$ from the third wash to cover the plate. Explant cell bodies were cut out using a 23 surgical blade, attached by suction to the tip of a pulled capillary, and transferred into the bottom of a $2 \mathrm{ml}$ ice-cold plastic test tube (Luckham). Ice-cold assay mix (50-100 $\mu \mathrm{l})$ was added immediately, and the tube was left on ice until all samples were collected. Films of neurites or neurite segments attached to the collagen substrate were collected by forming an incision in the collagen around the perimeter or within the neurite field with the scalpel blade and teasing the outer edges of the cut piece gently inwards until a film of neurites was floated off the plate. This film was transferred by suction to a test tube and treated similarly to the cell body region. When the collagen was of the right consistency films formed easily, as illustrated in Figure 1. Drier, thinner collagen $(0.2 \mathrm{ml}$ of 0.1 O.D. collagen dried overnight in desiccator) supported more rapid neurite outgrowth but intact neurites could not be detached from the plate.

AC activity was measured by the method of Salomon et al. (1974). The standard assay mix contained $50 \mathrm{~mm}$ Tris- $\mathrm{HCl}, \mathrm{pH} 7.4,11 \mathrm{~mm}$ $\mathrm{MgCl}_{2}, 2 \mathrm{~mm}$ cAMP, and $0.5 \mathrm{~mm}$ ATP (Boehringer), $6 \mathrm{~mm}$ creatine phosphate, and 5 units $/ 100 \mu$ lassay mix of creatine kinase (Boehringer), $0.06 \%$ Lubrol WX (Sigma), and sufficient $\alpha{ }^{-32} \mathrm{P}-\mathrm{ATP}(40-80 \mathrm{Ci} / \mathrm{mmol}$; Amersham International) to give a specific activity of $30-70 \mathrm{cpm} / \mathrm{pmol}$. Usually, $5 \mathrm{ml}$ of assay mix was prepared at a time, and aliquots were frozen at $-20^{\circ} \mathrm{C}$ in order to obtain a uniform solution for accurate comparison of early and later growth periods. Additional assay components (such as guanine nucleotides and forskolin) were added in 1-2 $\mu 1$ volumes to tubes still on ice. Tubes were then transferred to $37^{\circ} \mathrm{C}$ for
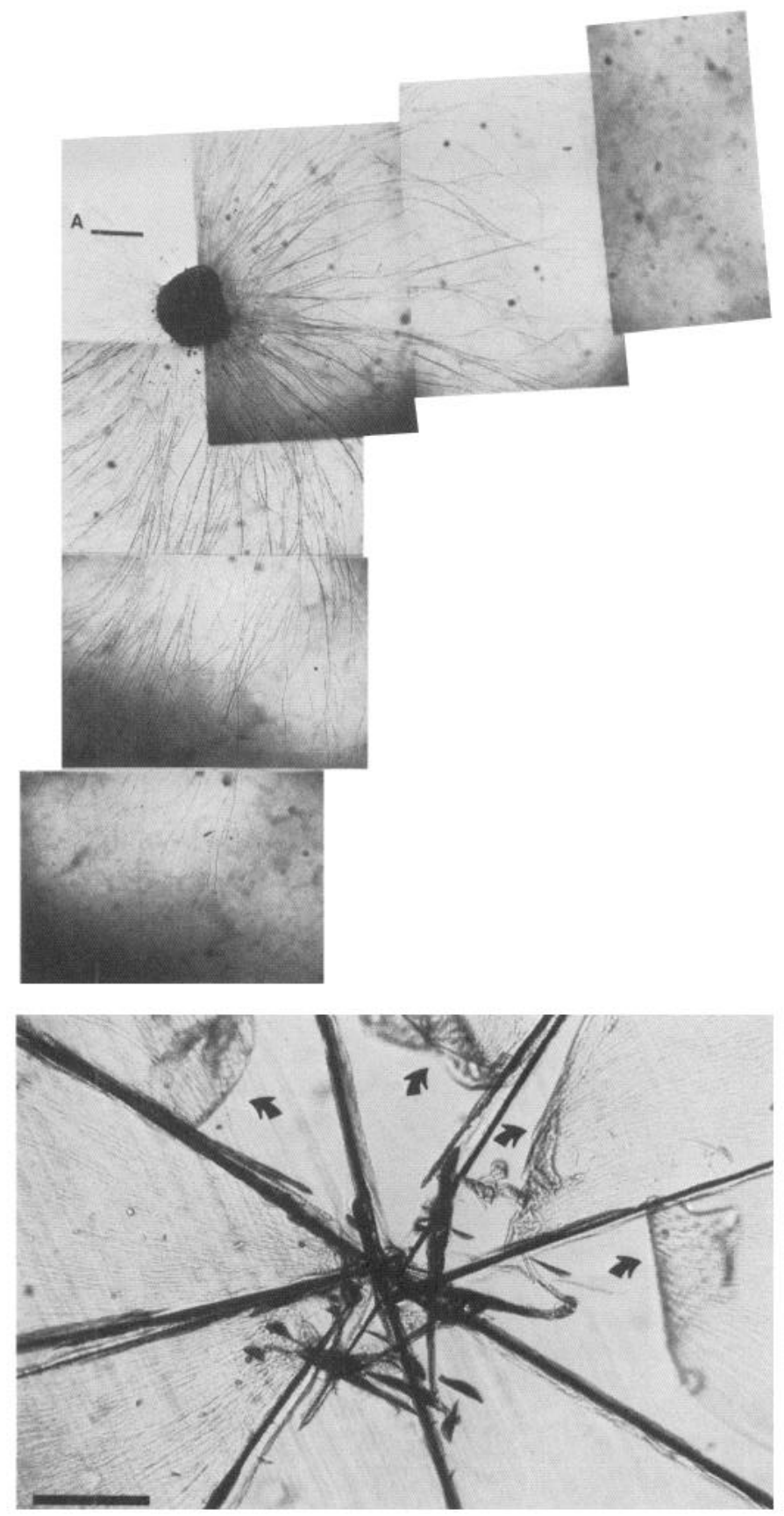

Figure 1. Dissection of cultured explants of rat SCG. Upper, $7 \mathrm{~d}$ culture before dissection. $\times 60$. Scale bar, $400 \mu \mathrm{m}$. Lower, dissected culture in which cell bodies have been removed and neurite field has been divided into 8 equal segments. Collagen with attached neurites is partially detached from some of the cut area, indicated by arrows. This and similar cultures were used to measure $G_{s}$ activity (see section $A$, Table 1).

1-2 $\mathrm{hr}$. The assay was stopped by the addition of $0.5 \mathrm{ml} 2 \% \operatorname{SDS}\left(50^{\circ} \mathrm{C}\right)$ and vigorous mixing. Activity was linear with time up to $2 \mathrm{hr}$ (in the presence of nonhydrolyzable GTP analogs) and proportional to the number of cultures added per assay. AC activity in dispersed cell cultures was measured after removal of medium by the addition of $150 \mu 1$ assay mix directly into the well formed in the petri dish. The assay was stopped by first collecting the supernatant into tubes containing $100 \mu 12 \%$ SDS. Rings were then removed and 2 washes of the plate with $0.5 \mathrm{ml} 2 \%$ SDS each were added to the tubes before cAMP separation. Blank values were $25 \pm 12$ (SD) cpm, as compared to $105-117 \mathrm{cpm}$ for the lowest levels of cAMP generated by the dispersed cell cultures (GDP $\beta$, day 

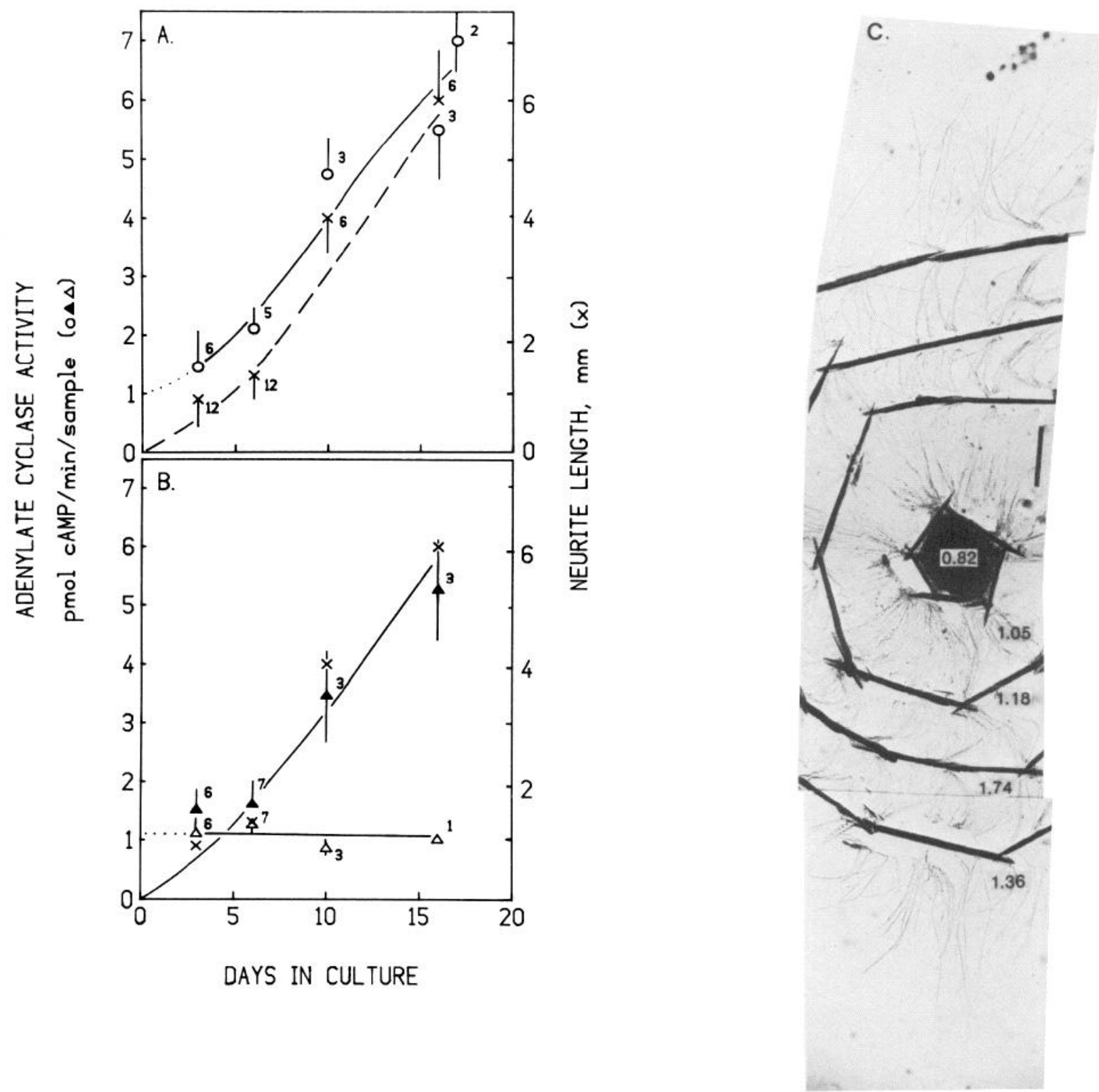

Figure 2. AC activity in explants as a function of age and neurite length. $A$, Explant cultures were removed as indicated and $\mathrm{AC}$ activity was measured for $60-100 \mathrm{~min}$ at $37^{\circ} \mathrm{C}$ in the presence of $10 \mu \mathrm{M} \mathrm{GTP} \gamma \mathrm{S}$ and $20 \mu \mathrm{M}$ forskolin (O). Neurite length was measured using a grid subdivided into $200 \mu \mathrm{m}$ squares $(\times) . B$, Cell bodies $(\Delta)$ and neurites $(\Delta)$ were separated and AC activity was measured in each segment as in $A$. $\times$, neurite length $(\mathrm{mm})$. $C$, Neurites from $8 \mathrm{~d}$ explant cultures were divided into 4 areas. The numbers in each segment represent AC activity in pmol cAMP/ $100 \mathrm{~min}$ at $37^{\circ} \mathrm{C} /$ segment. Magnification: $\times 60$. Scale bar, $400 \mu \mathrm{m}$.

zero; Fig. 3), and were between 100-200 cpm, as compared to $800-$ $1200 \mathrm{cpm}$ for the lowest levels of cAMP-generated by explant segments (GDP $\beta$ S; Table 1). Blank values were always subtracted before calculation of cAMP recovery from the columns.

Tyrosine hydroxylase (TH) activity was measured essentially by the method of Hendry and Iversen (1971). Cell bodies and neurites were collected as described above and transferred into microfuge test tubes containing $15 \mu \mathrm{l}$ of $5 \mathrm{~mm}$ Tris/Cl, $\mathrm{pH} 6.0$, and $0.1 \%$ Triton X-100 (Sigma). Tubes were frozen and thawed in liquid nitrogen, and cytosol was extracted by spinning tubes for $3 \mathrm{~min}$ at $4^{\circ} \mathrm{C}$ in a microfuge. Ten microliters of cytosol extract were added to $10 \mu \mathrm{l}$ ice-cold assay mix containing $0.18 \mathrm{~mm} \mathrm{~K} / \mathrm{Na} \mathrm{P}_{\mathrm{i}}$ buffer, $\mathrm{pH} 6,0.32 \mathrm{M} \beta$-mercaptoethanol (BDH biochemicals), 0.98 mM 6,7-dimethyl-5,6,7,8-tetrahydropterine hydrochloride (Aldrich), $2 \mu \mathrm{g}$ /assay NSD 1055 (a gift from Dr. Piers C. Emson, MRC Neurochemistry Unit, Cambridge), $80 \mu \mathrm{M}$ L-tyrosine (BDH biochemicals) containing L-[2,3-side chain $\left.{ }^{3} \mathrm{H}\right]$ tyrosine $(1560 \mathrm{cpm} / \mathrm{pmol}$; Amersham International), and $2.5 \mathrm{~mm}$ Tris $/ \mathrm{Cl}, \mathrm{pH} 6$, and $0.05 \%$ Triton $\mathrm{X}-100$; tubes were transferred to $37^{\circ} \mathrm{C}$ for $20 \mathrm{~min}$. Assays were linear between 10 and 20 min with these small amounts of material. ${ }^{3} \mathrm{H}-$ tyrosine $(100 \mu \mathrm{l}, 1 \mathrm{mCi} / \mathrm{ml})$ was added to $200 \mu \mathrm{l}$ of $0.53 \mathrm{~mm}$ Tris buffer, pH 6.8, containing $0.32 \mathrm{~mm}$ L-tyrosine and incubated with 2 lots of 1 mg neutral alumina (type WN3, Sigma) on ice before being added to the cocktail. Blank values were between 250 and $350 \mathrm{cpm}$, as compared to $550-600 \mathrm{cpm}$ (the lowest level of activity generated by noncultured explant pieces) to $\sim 7000 \mathrm{cpm}$ ( $29 \mathrm{~d}$ culture; Fig. 4). Blanks were subtracted before calculation of DOPA levels.

ADP-ribosylation and analysis of labeled products. Cell bodies and neurite segments were collected separately or together as described above. ADP-ribosylation labeling mixture contained $1.5 \mu \mathrm{g}$ pertussis toxin (Public Health Services Laboratory, Porton Down, Salisbury, U.K.) or $6 \mu \mathrm{g}$ cholera toxin (Calbiochem), $8 \mathrm{~mm}$ dithiothreitol, $100 \mathrm{mM} \mathrm{KP}$ buffer $\mathrm{pH} 7,0.08 \%$ Lubrol WX, 1-2 $\mu \mathrm{Ci} \alpha{ }^{32} \mathrm{P}-\mathrm{NAD}(0.1-0.2 \mu \mathrm{M}$ final concentration), $1 \mathrm{~mm}$ ATP, $10 \mathrm{~mm}$ thymidine, and $0.2 \mathrm{~mm}$ GTP (Boehringer) in a final volume of $61 \mu \mathrm{l}$. Toxins were preactivated for $30 \mathrm{~min}$ at $37^{\circ} \mathrm{C}$ in the same tubes used for the labeling in $10 \mu 150 \mathrm{~mm}$ dithiothreitol before addition of the other components. After $30 \mathrm{~min}$ at 
$30^{\circ} \mathrm{C}, 60 \mu$ l solubilizing buffer (as described by Laemmli, 1970) was added and samples were boiled for $3 \mathrm{~min}$. Proteins were separated by SDS-PAGE (Laemmli, 1970) and stained with silver by the method of Wray et al. (1981). Fuji RX X-ray film was exposed to dried gels for $1-7 \mathrm{~d}$ at $-80^{\circ} \mathrm{C}$ for autoradiography.

Determination of neurite volume. Single explants were grown on 12 $\mathrm{mm}$ glass coverslips precoated with $\sim 20 \mu \mathrm{l}$ of 0.3 O.D. $(280 \mathrm{~nm})$ collagen. A coverslip was placed in a thermostatically controlled $\left(36^{\circ} \mathrm{C}\right)$ chamber that was mounted on the stage of a Leitz Diavert fluorescence microscope with Leitz photomultiplier attachment. The explant was incubated with $5 \mu \mathrm{M}$ of the acetoxy methyl ester of $2^{\prime}, 7^{\prime}$-bis(carboxyethyl)5,6-carboxyfluorescein (BCECF) (Rink et al., 1982) in L15-air medium. After 5 min the solution was replaced with I.15-air, which was changed twice in succession. The explant was visualized using a $32 \times$ objective and the average fluorescence (excitation, $410-425 \mathrm{~nm}$; emission $>510$ $\mathrm{nm}$ ) emitted from an area of $150 \mu \mathrm{m}^{2}$ during $30 \mathrm{sec}$ was measured. The microscope stage was used to move the $150 \mu \mathrm{m}^{2}$ window, set by an attachment to the photomultiplier, from the center of the explant to the perimeter in successive steps of $150 \mu \mathrm{m}$. This scanning was repeated in several directions. A $0.4 \%$ transmission filter was used to prevent bleaching, and frequencies above $0.1 \mathrm{~Hz}$ were filtered.

\section{Results}

Regional distribution of $A C$ activity

Figure 2 shows an analysis of the distribution of AC activity stimulated by forskolin and $\mathrm{GTP} \gamma \mathrm{S}$ in neurites and cell bodies of explant SCG segments as a function of time in culture. Forskolin, which causes direct activation of the catalytic unit of AC (Seamon and Daly, 1981) and GTP $\gamma$ S, which activates the stimulatory GTP binding protein quasi-irreversibly, were added together to maximize $\mathrm{AC}$ activity and to minimize inactivation, which can occur at $37^{\circ} \mathrm{C}$ over long incubation periods in assay mixed in the absence of guanine nucleotides (Tamir and Tolkovsky, 1985). As shown in Figure $2 A$, total explant AC activity increased by about 7 -fold within $17 \mathrm{~d}$ in culture. Neurites grew about $6 \mathrm{~mm}$ during this time, establishing a constant growth rate of about $400 \mu \mathrm{m} / \mathrm{d}$ after an initial, slower period of growth during the first 2-3 d. The lag time was similar to that described by Agiro and Johnson (1982) for SCG from older animals, but the rate of neurite extension was usually faster than they described, similar to the rates of neurite extension obtained by Estridge and Bunge (1978). The pattern of growth was highly dependent on the concentration and physical state of the collagen, whose preparation was therefore standardized as described in Materials and Methods. An analysis of activities in separated neurite and cell body regions (Fig. $2 B$ ) shows that $\mathrm{AC}$ activity in the neurites rose at the same rate as $\mathrm{AC}$ activity in intact cultures, while levels of activity in the cell bodies remained virtually constant during growth. The level of $\mathrm{AC}$ activity expressed in neurites depended directly on neurite length. For example, AC activity in 4-mm-long neurites from a $17 \mathrm{~d}$ explant was identical to the activity in neurites obtained from $10 \mathrm{~d}$ culture of explants shown in Figure 2, which had also grown by $4 \mathrm{~mm}$.

The linear relationship between average neurite outgrowth and the increase in $\mathrm{AC}$ activity suggested that $\mathrm{AC}$ activity might be distributed throughout the neurites. It was also possible, however, that AC activity was localized in a discrete area of the neurite, such as the growth cone. To examine the pattern of distribution of AC activity in the neurites, neurites from explant cultures were dissected into $500 \pm 134-\mu \mathrm{m}$-wide segments in the form of concentric rings (Fig. $2 \mathrm{C}$ ). AC activity was present in each section, indicating the presence of $\mathrm{AC}$ throughout the neurites. The fact that $A C$ activity in each $0.5 \mathrm{~mm}$ segment also fell within $1 \mathrm{SD}$ of the average sectional AC activity [1.33 \pm $0.34 \mathrm{pmol} \mathrm{cAMP} / \mathrm{min}\left(37^{\circ} \mathrm{C}\right) /$ section in the presence of forskolin and $\mathrm{GTP}_{\gamma} \mathrm{S}$ and Table 1, below] suggested that AC activity may be evenly distributed along the neurites at $0.5 \mathrm{~mm}$ resolution. This interpretation assumes an equal volume of neurites in each concentric section. Equal amounts of AC activity per segment would also be obtained, however, if AC activity were kept constant per unit outgrowth despite an increase in branching as neurites extended. (Thus, $0.5 \mathrm{~mm}$ of 2 neurite branches preceded by $0.5 \mathrm{~mm}$ of an unbranched neurite segment would contain the same amount of total AC activity, but each branch would contain half the density of $\mathrm{AC}$.) To measure the volume of neurites per unit arca of outgrowth, neurites were loaded with the fluorescent indicator BCECF (Rink et al., 1982) (Fig. 3A). A photomultiplier attached to a fluorescence microscope (Rogers et al., 1983; Richards and Tolkovsky, 1986) measured the fluorescence emitted from a constant area $\left(150 \mu \mathrm{m}^{2}\right)$ of neurites. Sections of neurites were scanned in steps of $150 \mu \mathrm{m}$ from the center to the perimeter of the explant. If $n$ is the number of steps from the center to the perimeter of the explant, the fluorescence $/ 150 \mu \mathrm{m}^{2}$ in segment $n$ will be smaller by $1 /(2 n-1)$ relative to the fluorescence/ $150 \mu \mathrm{m}^{2}$ in segment $n=1$ if neurites grow in a radial pattern and the average volume per concentric section is constant. Figure $3 B$ shows that the fluorescence/ 150 $\mu \mathrm{m}^{2}$ was a linear function of $2 n-1\left(r^{2}=0.9135\right.$ for a linear regression), indicating that the volume of neurites per concentric segment does not increase with increasing neurite outgrowth from these explants.

\section{Colocalization of $A C$ and GTP binding proteins}

Regulation of $\mathrm{AC}$ activity by receptors for neurotransmitters and hormones is dependent on the function of 2 classes of GTP binding proteins ( $G$ proteins) known as $G_{s}$ and $G_{i}$, which promote stimulation and inhibition, respectively, of $A C$ when they bind GTP or nonhydrolyzable analogs of GTP such as GTP $\gamma$ or $\mathrm{p}(\mathrm{NH}) \mathrm{ppG}$. The function of $\mathrm{G}$ proteins is inhibited by the GDP analog, GDP $\beta$ S. The presence of stimulatory and inhibitory $G$ proteins in neurites was therefore examined to determine to what extent neurite $\mathrm{AC}$ activity can be modulated by guanine nucleotides early in development. Table 1 summarizes the effects of the nonhydrolyzable GTP and GDP analogs on AC activity in neurite segments after radial (section $A$ ) or concentric microdissection (sections $\mathrm{B}$ and $\mathrm{C}$; also illustrated in Fig. 2C). Activity measured in the presence of GDP $\beta S$ indicated that $\mathrm{AC}$ in all neuron segments has intrinsic (or basal) activity in the absence of stimulatory guanine nucleotides. GTP $\gamma \mathrm{S}$ or $\mathrm{p}(\mathrm{NH}) \mathrm{ppG}$ enhanced basal activity between 3 - and 10-fold regardless of whether the neurite segment was derived from a radial or a concentric section. Forskolin enhanced activity between 5 - and 15 -fold. The activation obtained by the addition of both forskolin and GTP $\gamma \mathrm{S}$ was similar to the sum of the 2 activities measured separately (shown in brackets in Table 1), consistent with the simultaneous expression of active $G_{s}$ and catalytic subunit of AC throughout the neurites.

Independent structural evidence for the presence of GTP binding proteins was sought by the use of pertussis and cholera toxins. Pertussis toxin catalyzes the ADP-ribosylation of $\mathrm{G}_{i}$ and of another $G$ protein found in brain, known as $G_{\circ}$ (Neer et al., 1984; Sternweis and Robishaw, 1984; Wong et al., 1985). Cholera toxin catalyzes the ADP-ribosylation of $G_{s}$ and some other $G$ proteins specific to brain membranes (Berthillier et al., 1982; Wong et al., 1985). Figure $4 A$ shows a gel on which proteins from cell bodies or neurites of $8 \mathrm{~d}$ cultures of SCG explants were separated by SDS-PAGE after incubation with either per- 

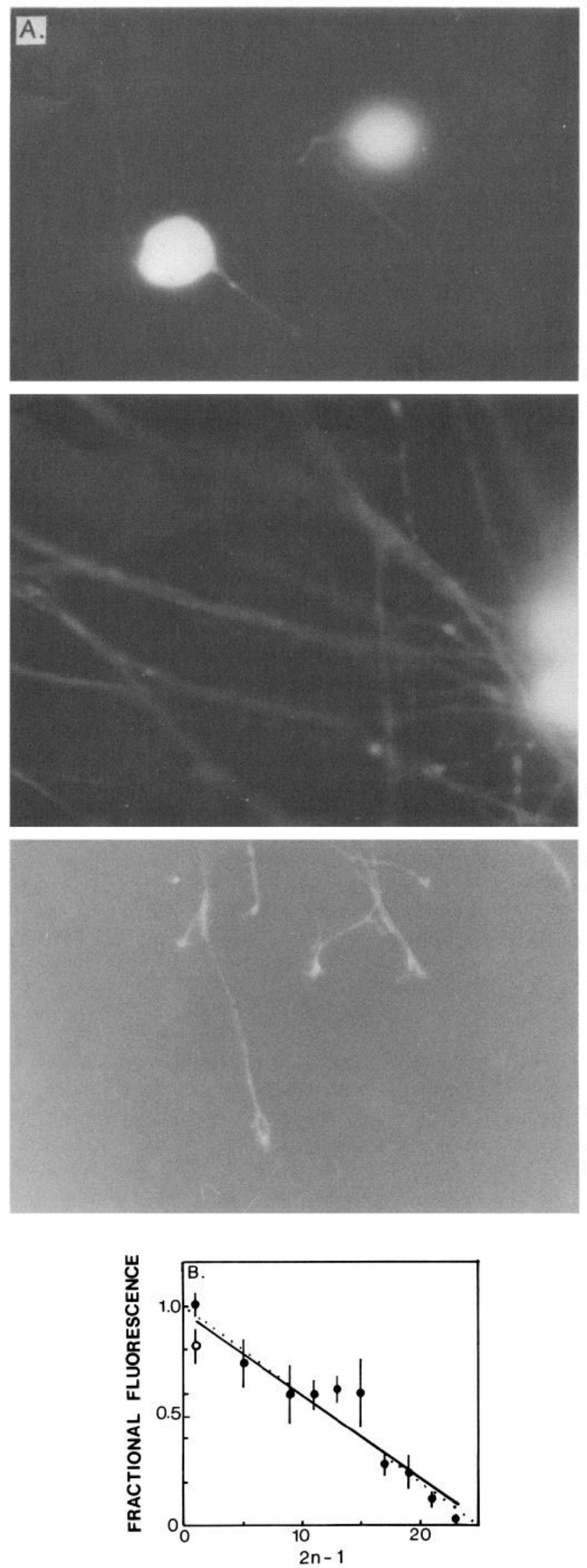

tussis or cholera toxin, GTP, and ${ }^{32} \mathrm{P}-\mathrm{NAD}$. The stained proteins derive from serum and from collagen, as well as from the cells. Neuronal actin was abundant and served as an internal molecular-weight standard for comparison with an actin marker added externally. The corresponding autoradiogram shows heavy labeling of a protein slightly smaller than $40 \mathrm{kDa} M_{\mathrm{r}}$ after incubation of either cell bodies or neurites with pertussis toxin. Figure $4 B$ shows that the same protein was labeled by pertussis toxin in neurites that were divided into 2 unequal sections comprising the anterior portion of the neurites $(\sim 85 \%)$ and the posterior portion $(\sim 15 \%)$. There was very slight labeling in the presence of cholera toxin, possibly because the affinity of cholera toxin for NAD and for the $52 \mathrm{kDa} \alpha$-subunit of $\mathrm{G}_{s}$ is very low (Berthillier et al., 1982; Wong et al., 1985). Cholera toxin did promote, however, some labeling of a protein the same size as the pertussis toxin substrate. Pertussis toxin also promoted intense labeling of a $\sim 40 \mathrm{kDa}$ protein when dispersed cultures of dorsal root ganglia neurons were ADP-ribosylated in situ using the same labeling cocktail (this experiment was performed in collaboration with Dr. Ann Mudge, University College, London), indicating that both sympathetic and sensory neurons contain large amounts of pertussis toxin substrate during development. The high density of the pertussis toxin substrate, and the fact that it was consistently smaller than creatine kinase, suggests that this protein is primarily $\mathrm{G}_{\mathrm{o}}$ (Neer et al., 1984; Sternweis and Robishaw, 1984; Wong et al., 1985), although the presence of $\mathrm{G}_{\mathrm{i}}$ cannot be excluded.

\section{Density of catalytic units of $A C$}

A quantitative assessment of the number of active AC and G protein molecules synthesized per cell could not be calculated in experiments with explant cultures since the number of cells that sprouted neurites was not known. AC activity was therefore measured in dispersed cultures of SCG neurons in which the number of neurons growing neurites was counted. Figure $5 \mathrm{~A}$ shows a typical pattern of development of cultures grown for $29 \mathrm{~d}$. Figure $5 B$ shows that basal, GTP $\gamma \mathrm{S}$-stimulated, and GTP $\gamma \mathrm{S}$ plus forskolin-stimulated activities of AC in dispersed cells increased as a function of time in culture. The amounts of cAMP produced under these 3 experimental conditions by $9 \mathrm{~d}$ cultures of $1800 \pm 300$ cells were similar to the amounts of cAMP produced by $150 \mathrm{ng}$ of adult rat brain membranes assayed under identical conditions, indicating that $\mathrm{AC}$ and $\mathrm{G}$ proteins are assembled in a mature state in the growing neurite. The number of molecules of AC in neural cell bodies, and the number of active $\mathrm{AC}$ molecules synthesized by a growing neuron per day

Figure 3. Fluorescence of BCECF from neurite sections as a function of distance from explant center. $A$, Cells loaded with BCECF: $t o p$, cell bodies; middle, edge of small explant with neurites; bottom, growth cones (Kodak Tri-X film). $\times 625$. B, Six-d-old explants were loaded with BCECF as described in Materials and Methods. The fractional fluorescence (fluorescence $(n)$ /fluorescence $(n=1))$ is plotted as a function of $2 n-$ $1(\bullet)$, where $n$ is the number of a $150 \mu \mathrm{m}^{2}$ segment in a linear sequence from $n=1$ in the neurite section most proximal to the cell bodies to $n=12$ for the most distal segment of neurites. The open circle is the fractional fluorescence in $n=1$ measured at the end of the experiment ( $\sim 30 \mathrm{~min})$. The average background fluorescence at $\times 300$ magnification used was 15 (in arbitrary units) as compared to 31 for $n=1$ at the beginning of the experiment. Background was subtracted before relative fluorescence was calculated. The mean \pm SD is shown for 5 determinations. Solid line is derived from a linear regression, $r^{2}=0.9135$; dotted line, theoretical curve. 
Table 1. Distribution of stimulatory $G$ protein $\left(G_{s}\right)$ in cell bodies and neurite segments

Adenylate cyclase activity (pmol cAMP/100 min/segment)

\begin{tabular}{|c|c|c|c|c|c|c|}
\hline & \multicolumn{6}{|c|}{ Adenylate cyclase activity (pmol cAMP/100 min/segment) } \\
\hline & \multirow{2}{*}{$\begin{array}{l}\text { GDP } \beta S \\
(100 \mu \mathrm{M}) \\
\end{array}$} & \multirow{2}{*}{$\begin{array}{l}\text { GTP } \gamma \mathrm{S} \\
(10 \mu \mathrm{M}) \\
\end{array}$} & \multirow{2}{*}{$\begin{array}{l}\text { for- } \\
\text { skolin } \\
(20 \mu \mathrm{M})\end{array}$} & \multicolumn{2}{|c|}{$\begin{array}{l}\text { GTP } \gamma \mathrm{S}+ \\
\text { forskolin } \\
\end{array}$} & \multirow{2}{*}{$\begin{array}{l}\mathrm{p}[\mathrm{NH}] \mathrm{ppG} \\
(100 \mu \mathrm{M})\end{array}$} \\
\hline Sample & & & & $10 \mu \mathrm{M}$ & $20 \mu \mathrm{M}$ & \\
\hline \multicolumn{7}{|c|}{ A. Neurites divided into 8 radial sections } \\
\hline Explant (i) & $2.7 \pm 0.3(3)$ & $34.3 \pm 0.3(2)$ & 33 & \multicolumn{2}{|c|}{$77.5[67.3]$} & \\
\hline Explant (ii) & $4.1 \pm 0.5(3)$ & $23.2 \pm 2.2(2)$ & 54.5 & \multicolumn{2}{|c|}{$104.4[77.7]$} & \\
\hline Explant (iii) & $3.6 \pm 0.4(3)$ & $9.0 \pm 1.3(2)$ & 11.1 & \multicolumn{2}{|c|}{$27.8[20.1]$} & \\
\hline \multicolumn{7}{|c|}{ B. Neurites divided into 2 concentric sections } \\
\hline Cell bodies & 10.5 & $52.6 \pm 5 \quad(2)$ & 151 & & & $41.1 \pm 11.1(2)$ \\
\hline Inner $\mathrm{n}$. area & 6.5 & $53.7 \pm 6.1(2)$ & 141 & & & 61.6 \\
\hline Outer n. area & 3.5 & $45.7 \pm 7.6(2)$ & 117 & & & 42.4 \\
\hline \multicolumn{7}{|c|}{ C. Neurites divided into 4 concentric sections } \\
\hline Cell bodies & $15 \pm 5$ & $39 \pm 15$ & 82 & 186 & {$[121]$} & \\
\hline $0-500 \mu \mathrm{m}$ & $23 \pm 5$ & $70 \pm 21$ & 118 & 14 & [188] & \\
\hline $500-1000 \mu \mathrm{m}$ & $25 \pm 7$ & $69 \pm 13$ & 105 & 174 & [174] & \\
\hline $1000-1500 \mu \mathrm{m}$ & $37 \pm 9$ & $54 \pm 13$ & 175 & 176 & [229] & \\
\hline $1500-2000 \mu \mathrm{m}$ & $38 \pm 3$ & $96 \pm 3$ & 136 & 210 & [232] & \\
\hline
\end{tabular}

$A$, Neurites of SCG explants ( $5 \mathrm{~d}$ cultures) were divided into 8 radial sections as illustrated in Figure $1 B$. The results in each row are derived from 1 culture and represent AC activity in 1-3 separate $1 / 8$ segments. $B$, Neurites of SCG explants ( $6 \mathrm{~d}$ cultures) were divided into 2 concentric sections approximately $1 \mathrm{~mm}$ wide. AC activity was meaured in the cell body region (top row), the inner neurite region (middle row), and the outer neurite region (bottom row). $C$, Neurites of SCG explants ( $8 \mathrm{~d}$ cultures) were divided into 4 concentric sections as illustrated in Figure $2 C$. AC activity was measured in the cell body region (top row) and in 4 neurite sections $500 \pm 134 \mu \mathrm{m}$ wide (activity in inner to outer sections in rows $2-5$ ). Enzyme assays were run for $100 \mathrm{~min}$ at $37^{\circ} \mathrm{C}$. The means and range of values $(n=2)$ or SD $(n=3)$ are followed by the number of replicates (in parentheses); the sum of GTP $\gamma$ S and forskolin activities is given in brackets.

A.

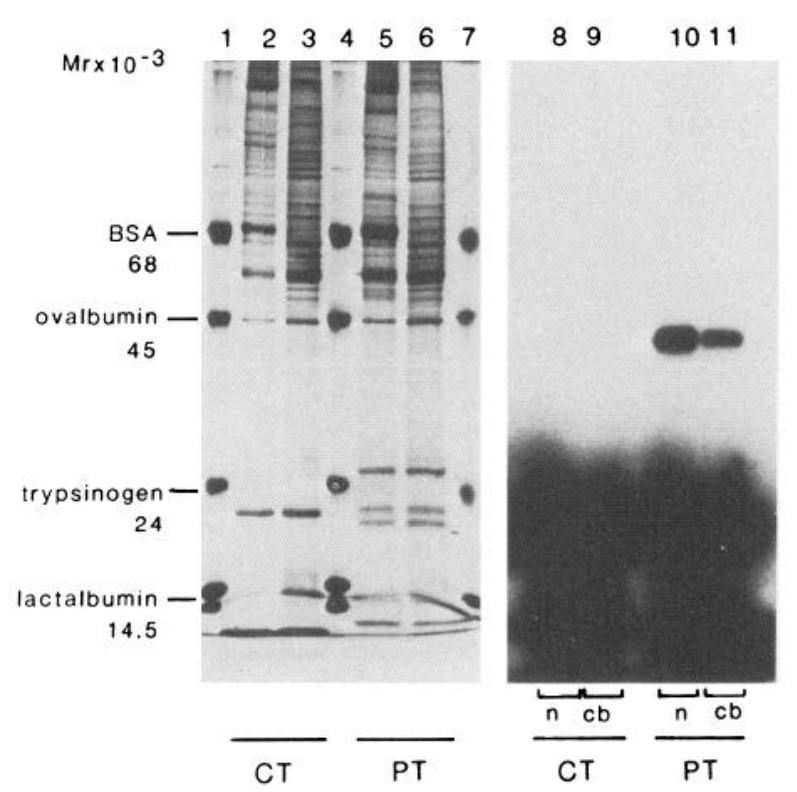

B.

a b c d e f g h

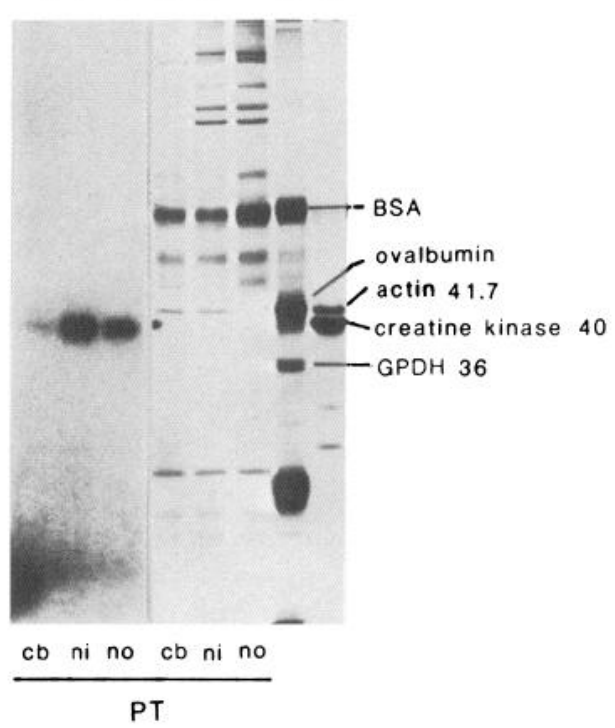

Figure 4. ADP-ribosylation of explant proteins by pertussis and cholera toxin. $A$, SDS-PAGE of cell body and neurite proteins from $8 \mathrm{~d}$ explants. Pertussis toxin $(P T)$ lanes $5,6,10,11$; cholera toxin $(C T)$ lanes $2,3,8,9 ; 4$ explant cell bodies $(c b$, lanes $3,6,9,11)$ or 4 explant neurites $(n$, lanes $2,5,8,10$ ) per lane; lanes $1-7$, silver-stained gel (lanes $1,4,7$ : molecular-weight markers; note the actin band in lanes $2,3,5,6$, just below the ovalbumin band); lanes 8-11, autoradiography ( $3 \mathrm{~d}$ exposure). The dark, lower region of the autoradiogram was caused by trapping of bulk ${ }^{32} \mathrm{P}$ compounds at and above the dye front. $B$, Three-day-old explants were divided into 3 segments: cell bodies $(c b$, lanes $a, d)$; inner neurite area, $\sim 80 \%$ of total neurite outgrowth ( $n i$, lanes $b, e$ ); and outer neurite area, including growth cones (no, lanes $c, f)$. Two explant segments were used for each lane; autoradiogram was exposed for $24 \mathrm{hr}$. Molecular-weight markers, lanes $g, h$. Note alignment of cellular actin with marker actin (lanes d-f and $h$ ). 

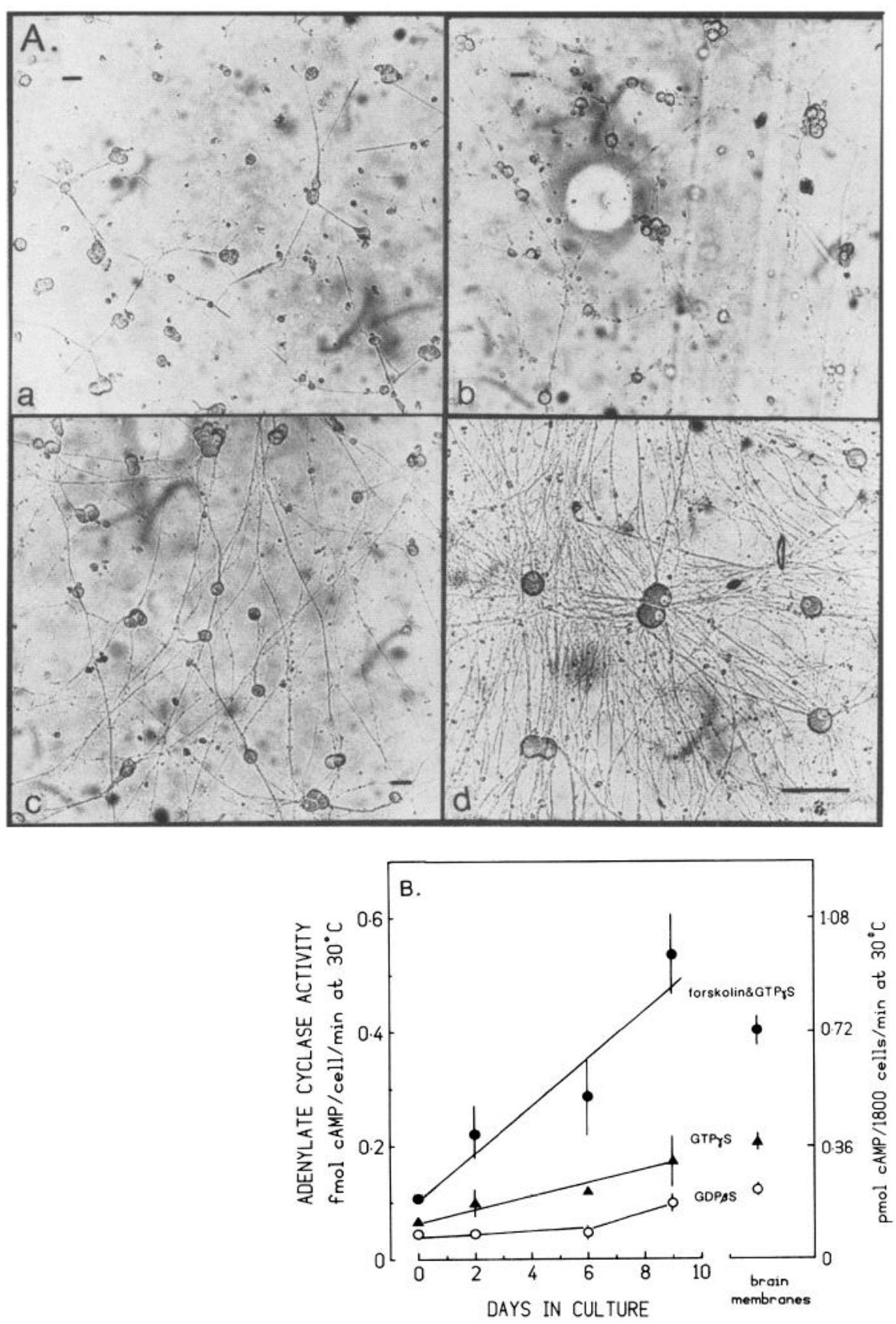

Figure 5. AC activity in cultures of isolated SCG neurons. $A$, SCG neurons maintained in culture for $1(a), 3(b), 6$ $(c)$, and $29(d)$ d. Magnification: $\times 125$ $(a-c) ; \times 400(d)$. Scale bar, $50 \mu \mathrm{m} . B$, $A C$ activity measured in the presence of $100 \mu \mathrm{m}$ GDP $\beta$ S (O), $10 \mu \mathrm{m}$ GTP $\gamma \mathrm{S}$ $(\mathbf{\Delta})$, or $10 \mu \mathrm{M} \mathrm{GTP} \gamma \mathrm{S}$ and $10 \mu \mathrm{M}$ forskolin (๑). Each point was obtained from $1800 \pm 300$ cells, counted from 20 fields at $\times 200$. Zero time points were obtained from the same number of cells counted as viable before seeding. AC activity in a preparation of rat brain synaptosomal membrane protein was measured under identical assay conditions, using the same assay cocktail. Bars represent range of values for 3 replicates. Lines were drawn by eye.

were estimated using a turnover number of $2000 / \mathrm{min}$ for GTP $\gamma \mathrm{S}$ stimulated AC similarly measured at $30^{\circ} \mathrm{C}$, based on the assumption that the turnover number is the same for different systems (Pfeuffer et al., 1983); a cell body that produced an average of $236 \pm 46$ attomol cAMP/min $\left(30^{\circ} \mathrm{C}\right)$ would contain approximately $70,000 \pm 10,000$ molecules of $\mathrm{AC}$ at the time of excision. The additional $52.6 \pm 20$ attomol $\mathrm{cAMP} / \mathrm{min}\left(30^{\circ} \mathrm{C}\right)$ produced after $24 \mathrm{hr}$ of growth would be equivalent to the addition of approximately $15,000 \pm 5000 \mathrm{AC}$ molecules. Furthermore, based on the assumption that $A C$ and $G_{s}$ are plasma membrane proteins, it was calculated that the surface of a cell body with a $\sim 30 \mu \mathrm{m}$ diameter (Fig. $5 A$ ) would contain 22-28 molecules of $\mathrm{AC} / \mu \mathrm{m}^{2}$ and that the surface of a neurite, a cylinder of $0.5 \mu \mathrm{m}$ diameter (Fig. $5 A$ ), would contain 9-15 molecules
$\mathrm{AC} / \mu \mathrm{m}^{2}$. These results suggest that cell body and neurite membranes contain similar densities of AC coupled to $G_{s}$.

\section{Reduction of $A C$ levels by tunicamycin}

The rapid addition of $\mathrm{AC}$ molecules in growing neurites prompted an examination of its rate of turnover. AC is reported to bind wheat germ agglutinin (Pfeuffer et al., 1985), and it was therefore tested whether levels of AC activity would be reduced by tunicamycin, which blocks $N$-asparagine-linked glycosylation. No direct effect of tunicamycin on AC activity was observed, and neurite morphology, as well as the rate of neurite outgrowth, appeared normal after $24 \mathrm{hr}$ in the presence of $2 \mu \mathrm{g} / \mathrm{ml}$ tunicamycin. Thus, neurite length increased by $20 \%$ in both control and tunicamycin-treated cultures but $\operatorname{GTP} \gamma \mathrm{S}$ plus forskolin- 


\begin{tabular}{|c|c|c|c|}
\hline Dissected area & Control & + tunicamycin & $\%$ of control \\
\hline \multicolumn{4}{|c|}{ a. $\mathrm{AC}$ activity (pmol cAMP/min/section) } \\
\hline Cell bodies & $1.10 \pm 0.13$ & $0.61 \pm 0.05$ & $55 \pm 8^{a}(90-35)$ \\
\hline Neurites & $3.60 \pm 0.61$ & $1.11 \pm 0.17$ & $31 \pm 7^{a}(67-15)$ \\
\hline \multicolumn{4}{|c|}{ b. Activity ratios } \\
\hline $\begin{array}{l}\text { Neurites/ } \\
\text { cell bodies }\end{array}$ & $3.26 \pm 0.68$ & $1.86 \pm 0.33$ & $57 \pm 33^{b}$ \\
\hline \multicolumn{4}{|c|}{ c. Elongation $(\%)$} \\
\hline Neurites & $20.8 \pm 8$ & $22.2 \pm 10$ & \\
\hline
\end{tabular}

Explants were cultured for $10 \mathrm{~d}$. A solution of $2 \mu \mathrm{g} / \mathrm{ml}$ tunicamycin was preparcd in $\mathrm{L} 15-\mathrm{CO}_{2}$ growth medium and was used to replace the normal medium. After $24 \mathrm{hr}$, cultures were dissected and $\mathrm{AC}$ activity measured for $100 \mathrm{~min}$ at $37^{\circ} \mathrm{C}$ in the presence of $10 \mu \mathrm{M}$ GTP $\gamma$ S and $10 \mu \mathrm{M}$ forskolin (section a). Ratios of neurite to cell body activities are given in section $b$. For calculation of the percentage of elongation, the average length of neurites in each culture was measured before and after $24 \mathrm{hr}$ in the presence or absence of tunicamycin (section c). Averages \pm SE. Means are given $(n=6)$ with the range of values in parentheses.

a $p<0.01$, double tailed Student's $t$ test.

${ }^{b} p<0.05$, double tailed Student's $t$ test.

stimulated activity was reduced to $55 \pm 8 \%($ SEM, $n=6)$ of control (10-65\% range of values) in cell bodies and to $31 \pm 7 \%$ (SEM, $n=6$ ) of control (33-90\% range of values) in neurites after $24 \mathrm{hr}$ (Table 2). This difference was significant at the $95 \%$ level (double-tailed Student's $t$ test). After $2-3 \mathrm{~d}$ in the presence of tunicamycin neurites disintegrated into a series of beads, similar to the appearance of neurites detached from cell bodies or of cells deprived of NGF. Thus, tunicamycin can reduce the amount of active AC without impairing neurite outgrowth.

\section{Comparison of $A C$ and $T H$ distribution}

The distribution of $\mathrm{AC}$ and $\mathrm{TH}$ activities between cell bodies and neurites and the rate of their appearance were compared for 3 main reasons: (1) TH controls the rate of catecholamine biosynthesis and may be considered to be a specific maturation marker for adrenergic neurons (Black and Patterson, 1980; Wolinsky and Patterson, 1983; but also Iacovitti et al., 1981); (2) the levels of activity and the expression of TH in SCG increases in response to acute and long-term exposure to NGF and other extracellular stimuli (Hefti et al., 1982; Ip et al., 1983), and TH activity is enhanced after phosphorylation by cAMP- and $\mathrm{Ca}^{2+}$ calmodulin-dependent protein kinases (Treiman et al., 1983; Niggli et al., 1984); (3) unlike AC, it is a cytosolic rather than an integral membrane protein. Figure $6 A$ shows that the rise in TH activity was parallel to the rise in $\mathrm{AC}$ activity up to $10 \mathrm{~d}$ in culture. After $10 \mathrm{~d}$, TH activity increased more rapidly than the rate of neurite outgrowth, but between $20-29 \mathrm{~d}$ the rate of increase in $\mathrm{TH}$ activity appeared to decrease; this is similar to the time course of TH induction in cultures of dispersed SCG neurons described by Mains and Patterson (1973). On comparing the distribution of $\mathrm{TH}$ and $\mathrm{AC}$ activities in cell bodies and neurites during $17 \mathrm{~d}$ of growth (Fig. $6 \mathrm{~B}$ ), cell bodies were found to retain $85 \pm 3 \%$ of total cellular TH activity, while the proportion of total cellular AC activity in cell bodies fell rapidly during growth, and only $15 \pm 2 \%$ was found in cell bodies after $17 \mathrm{~d}$.

\section{Discussion}

The present study shows that SCG neurons synthesize an AC system, consisting of catalytic and regulatory components, con-
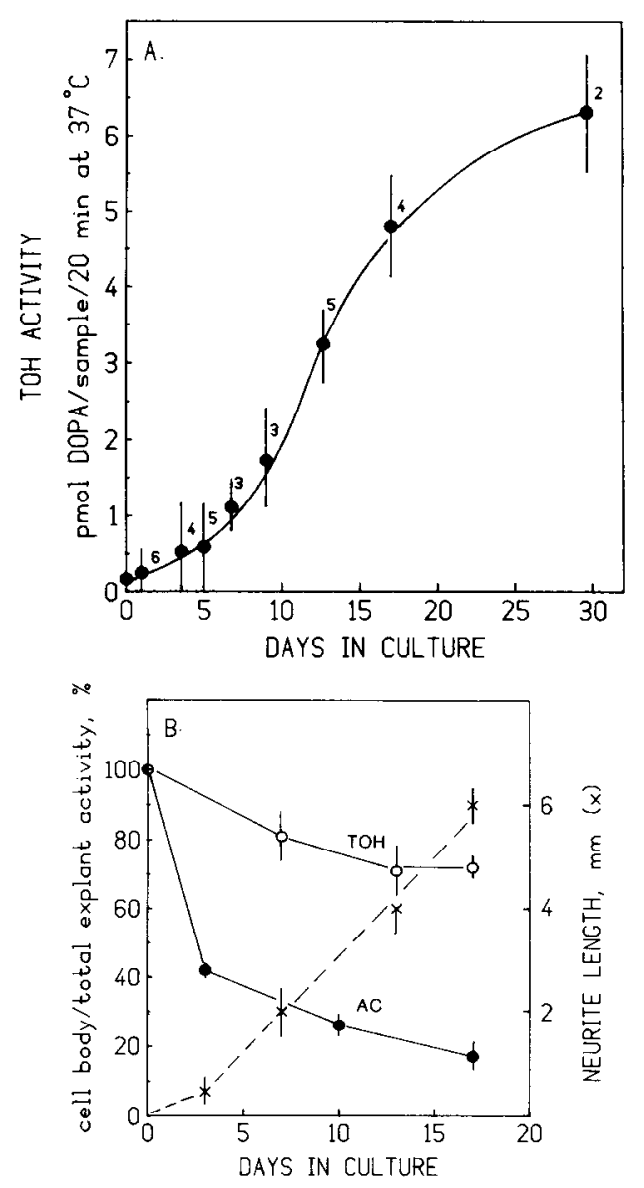

Figure 6. TH activity in explants. $A$, TH activity measured for $20 \mathrm{~min}$ at $37^{\circ} \mathrm{C}$ as described in Materials and Methods. $B$, Fraction of total explant $\mathrm{TH}(\mathrm{O})$ and $\mathrm{AC}(\bullet)$ activitics found in ccll bodies plotted against time in culture. $\times$, neurite length $(\mathrm{mm})$.

comitantly with neurite outgrowth and express this system throughout the neuron during development. The rate of increase in $\mathrm{AC}$ activity is directly proportional to the rate of neurite outgrowth; it is dependent on neurite length and independent of the number of days in culture. The AC system appears to be widely distributed in the cell, as has been previously shown for $\mathrm{Na} / \mathrm{K}$-ATPase in chick dorsal root ganglia neurons (Fambrough et al., 1985) and the voltage-dependent $\mathrm{Na}$ channel in various unmyelinated neurons (Rogart, 1983). The presence of a competent AC system in developing neurites suggests that the CAMPdependent protein kinase found in growth cone particles isolated from the developing fetal brain (Ellis et al., 1985) can be activated by the local production of cAMP.

The decrease in AC activity after exposure to tunicamycin is similar to the decrease of voltage-dependent $\mathrm{Na}$ channels observed in cultured muscle cells (Sherman et al., 1985). The somewhat smaller decline in cell body AC after tunicamycin treatment as compared to neurite $\mathrm{AC}$ raises the possibility that insertion of newly synthesized $\mathrm{AC}$ is more vigorous in the neurite than in the cell body, corresponding to the pattern reported for the inscrtion of newly synthesized membrane lipids into growing neurites (Pfenninger and Johnson, 1983). Carbonetto and Fambrough (1979), however, found that newly synthesized $\alpha$-bungarotoxin binding sites on sympathetic neurons were inserted into cell bodies and neurites at an equal rate, despite the fact that the binding sites were more dense on the cell body than 
on the neurite. The regulation of the synthesis of the $\alpha$-bungarotoxin receptor was also different from $\mathrm{AC}$, increasing to a maximum within $3 \mathrm{~d}$ but declining to basal levels within $7 \mathrm{~d}$. Thus, mechanisms that are secondary to membrane protein biogenesis may control sites of incorporation of different membrane constituents, similar to the control of $\mathrm{H}^{+}$-ATPase and $\mathrm{Cl}^{-} / \mathrm{HCO}_{3}$ carrier insertion into apical and basal membranes of kidney tubule cells (Schwartz et al., 1985).

There is only a small amount of data concerning the density of $\mathrm{AC}$ in neurons with which to compare the densities of $\mathrm{AC}$ calculated here. AC activity has been measured in cell bodies of the defined molluscan neurons D2, E2, and F1 by Deterre et al. (1982). The cell bodies of the molluscan neurons had approximately 10 - to 15 -fold larger diameters compared to the SCG neurons and contained approximately 20-fold higher AC activity. If the surface area is inferred from the diameter, the calculated density of $\mathrm{AC}$ per unit cell surface area is found to be similar for SCG and these neurons. However, it should be pointed out that this comparison is only approximate because the somatic membranes of molluscan ncurons are known to bc highly convoluted. A density of 9-28 molecules $/ \mu \mathrm{m}^{2}$ membrane surface is within the lower range of values given for the density of the voltage-dependent $\mathrm{Na}$ channels in various unmyelinated neurons (Rogart, 1983). It is about 100-fold lower than the lowest density given for soybean agglutinin, cholera, or tetanus toxin binding sites on cultured SCG neurons (allowing for 2060 molecules ligand/gold particle; Schwab and Landis, 1981). This difference may not be surprising, considering the fact that the toxin and the lectin binding sites are gangliosides, not proteins.

The limitation of the technique described for localizing enzymes in neurite fragments at present is the spatial resolution of the microdissection, and methods to obtain higher resolution and a more accurate basis for the measurement of specific activity are now being developed. Having shown that an AC system that can be regulated by guanine nucleotides is maintained in neurites during development, it is now of interest to establish the amount of intracellular cAMP this system generates and to correlate this with endogenous protein kinase activity during development.

\section{Appendix-Abbreviations}

The following abbreviations are used: $\mathrm{AC}$, adenylate cyclase; $\mathrm{TH}$ or TOH, tyrosine hydroxylase; $G$ protein, $G T P$ binding protein; $G_{s}$ and $G_{i}$, stimulatory and inhibitory GTP binding proteins of the adenylate cyclase systems; $G_{o}$, an abundant $G$ protein found in brain membranes; GTP $\gamma \mathrm{S}$, guanosine $5 '-\left[\gamma\right.$-thio]triphosphate; GDP $\beta S$, guanosine $5^{\prime}-[\beta-$ thio]diphosphate; $\mathrm{p}(\mathrm{NH}) \mathrm{ppG}$, guanosine $5^{\prime}-[\beta \gamma$-imido $]$ triphosphate; $\mathrm{CT}$, cholera toxin; PT, pertussis toxin; BCECF, 2'7'bis(carboxyethyl) 5-6 carboxyfluorescein; amol, attomol $\left(10^{-18} \mathrm{~mol}\right)$.

\section{References}

Agiro, V., and M. I. Johnson (1982) Patterns and kinetics of neurite extension from sympathetic neurons in culture are age dependent. J. Neurosci. 2: 503-512.

Berthillier, B., J. D'Alayer, and A. Monneron (1982) ADP-ribosylation of brain synaptosomal proteins correlates with adenylate cyclase activation. Biochem. Biophys. Res. Commun. 109: 297-304.

Black, I. B., and P. H. Patterson (1980) Developmental regulation of neurotransmitter phenotype. Curr. Top. Dev. Biol. 15: 27-65.

Bornstcin, M. B. (1958) Reconstituted rat tail collagen used as substrate for tissue cultures on coverslips in Maximow slides and roller tubes. Lab. Invest. 7: 134-137.

Carbonetto, S., and D. M. Fambrough (1979) Synthesis, insertion into the plasma membrane and turnover of $\alpha$-bungarotoxin receptors in chick sympathetic neurons. J. Cell Biol. 81: 555-569.

Deterre, P., D. Paupardin-Tritsch, J. Bockaert, and H. M. Gershenfeld (1982) cAMP mediated decrease in $\mathrm{K}^{+}$conductance evoked by serotonin and dopamine in the same neuron: $A$ biochemical and physiological single cell study. Proc. Natl. Acad. Sci. USA 79: 7934-7938.

Dunwiddie, T. V., and Hoffer, B. J. (1982) The role of cyclic nucleotides in the nervous system. In Handbook of Experimental Pharmacology, Vol. 58, Part II, J. W. Kebabian and J. A. Nathanson, eds., pp. 389-463, Springer-Verlag, New York.

Ellis, L., F. Katz, and K. H. Pfenninger (1985) Nerve growth cones isolated from fetal rat brain. II. Cyclic AMP binding proteins and cyclic AMP dependent protein phosphorylation. J. Neurosci. 5: 13931401.

Estridge, M., and R. Bunge (1978) Compositional analysis of growing axons from rat sympathetic neurons. J. Cell Biol. 79: 138-155.

Fambrough, D. M., B. A. Wolitzki, and D. W. Pumplin (1985) Developmental and regulatory aspects of the sodium- and potassium ion stimulated ATPase in avian nerve and muscle. In Regulation and Development of Membrane Transport Processes, J. S. Graves, ed., pp. 265-282, Wiley, New York.

Hawrot, E., and P. H. Patterson (1979) Long term culture of dissociated sympathetic neurons. Methods Enzymol. 58: 574-584.

Hefti, F., H. Gnahm, M. E. Schwab, and H. Thoenen (1982) Induction of tyrosine hydroxylase by nerve growth factor and by elevated $\mathrm{K}^{+}$ concentrations in cultures of dissociated sympathetic neurons. J. Neurosci. 2: 1554-1566.

Hendry, I. A., and L. L. Iversen (1971) Effects of nerve growth factor and its antiserum on tyrosine hydroxylase activity in mouse superior cervical ganglion. Brain Res. 29: 159-162.

Iacovitti, L., T. H. Joh, D. H. Park, and R. P. Bunge (1981) Dual expression of neurotransmitter synthesis in cultured autonomic neurons. J. Neurosci. 1: 685-690.

Ip, N. Y., R. L. Perlman, and R. E. Zigmond (1983) Acute transynaptic regulation of tyrosine 3-monooxygenase activity in the SCG: Evidence for both cholinergic and noncholinergic mechanisms. Proc. Natl. Acad. Sci. USA 80: 2081-2085.

Kandel, E. R., T. Abrams, L. Bernier, T. J. Carea, R. D. Hawkins, and J. H. Schwartz (1983) Classical conditioning and sensitization share aspects of the same molecular cascade in Aplysia. Cold Spring Harbor Symp. Quant. Biol. 48: 821-830.

Katz, F., L. Ellis, and K. H. Pfenninger (1985) Nerve growth cones isolated from fetal rat brain. III. Calcium dependent protein phosphorylation. J. Neurosci. 5: 1402-1410.

Laemmli, U.K. (1970) Cleavage of structural proteins during assembly of the head of bacteriophage T4. Nature 227: 680-685.

Mains, R. E., and P. H. Patterson (1973) Primary cultures of dissociated neurons. II. Initial studies on catecholamine metabolism. J. Cell Biol. 59: 346-360.

Mobley, W. C., A. Schenker, and E. M. Shooter (1976) Characterization and isolation of proteolytically modified nerve growth factor. Biochemistry 15: 5543-5551.

Mulder, A. H., and A. N. M. Schoffelmeer (1985) Catecholamine and opioid receptors, presynaptic inhibition of CNS neurotransmitter release, and adenylate cyclase. Adv. Cyclic Nucleotide Protein Phosphoryl. Res. 19: 273-286.

Nairn, A. C., H. C. Hemmings, and P. Greengard (1985) Protein kinases in the brain. Annu. Rev. Biochem. 54:931-976.

Niggli, V., D. E. Knight, P. F. Baker, A. Vigny, and J. P. Henry (1984) Tyrosine hydroxylase in "leaky" adrenal medullary cells: Evidence for in situ phosphorylation by separate $\mathrm{Ca}^{2+}$ and cAMP-dependent systems. J. Neurochem. 43: 646-658.

Neer, E. J., J. M. Lok, and L. C. Wolf (1984) Purification and properties of the inhibitory guanine nucleotide regulatory unit of brain adenylate cyclase. J. Biol. Chem. 259: 14222-14229.

Novak Hofer, I., J. R. Lemos, M. Villermain, and I. B. Levitan (1985) Calcium and cyclic nucleotide dependent protein kinases and their substrates in the Aplysia nervous system. J. Neurosci. 5: 151-159.

Pfenninger, K. H., and M. P. Johnson (1983) Membrane biogenesis in sprouting neurons. 1. Selective transfer of newly synthesised phospholipid into the growing neurite. J. Cell Biol. 97: 1038-1042.

Pfeuffer, T., B. Gaugler, and H. Metzger (1983) Isolation of homologous and heterologous complexes between catalytic and regulatory components of adenylate cyclase by forskolin-Sepharose. FEBS Lett. I64: 154-160. 
Pfeuffer, E., R.-M. Dreher, H. Metzger, and T. Pfeuffer (1985) Catalytic unit of adenylate cyclase: Purification and identification by affinity cross linking. Proc. Natl. Acad. Sci. USA 82: 3086-3090.

Richards, C. D., and A. M. Tolkovsky (1986) The regulation of $\mathrm{pH}$ in rat superior ccrvical ganglion cells grown in tissuc culturc. J. Physiol. (Lond.) 373: 41P.

Rink, T. J., R. Y. Tsien, and T. Pozzan (1982) Cytoplasmic pH and $\mathrm{Mg}^{2+}$ concentration in lymphocytes. J. Cell Biol. 95: 189-196.

Rogart, P. (1983) Sodium channels in nerve and muscle membrane. Annu. Rev. Physiol. 43: 711-725.

Rogers, J., R. Hesketh, G. A. Smith, M. A. Beavan, J. C. Metcalfe, P. Johnson, and P. A. Garland (1983) Intracellular pH and free calcium changes in single cells using quene 1 and quin 2 probes and fluorescence microscopy. FEBS Lett. 161: 21-27.

Salomon, Y., C. Londos, and M. Rodbell (1974) A highly sensitive adenylate cyclase assay. Anal. Biochem. 58: 541-548.

Schoffelmeer, A. N. M., F. Hogenboom, and A. N. Mulder (1985) Evidence for presynaptic adenylate cyclase system facilitating $\left({ }^{3} \mathrm{H}\right)$ norepinephrine release from rat brain neocortex slices and synaptosomes. J. Neurosci. 5: 2685-2689.

Schwab, M., and S. C. Landis (1981) Membrane properties of cultured rat sympathetic neurons: Morphological studies of adrenergic and cholinergic differentiation. Dev. Biol. 84: 67-78.

Schwartz, G. J., J. Barasch, and Q. Al-Awqati (1985) Plasticity of functional epithelial polarity. Nature 318: 368-371.

Seamon, K., and J. W. Daly (1981) Activation of adenylate cyclase by the diterpene forskolin does not require the guanine nucleotide regulatory protein. J. Biol. Chem. 256: 9799-9801.
Sherman, S. J., J. Chrivia, and W. A. Catterall (1985) Cyclic AMP and cytosolic calcium exert opposing effects on biosynthesis of TTXsensitive sodium channels in rat muscle cells. J. Neurosci. 5: 15701576.

Sternweis, P. C., and J. B. Robishaw (1984) Isolation of two proteins of high affinity for guanine nucleotides from membranes of bovine brain. J. Biol. Chem. 259: 13806-13818.

Tamir, A., and A. M. Tolkovsky (1985) Transient states of adenylate cyclase in brain membranes. J. Neurochem. 44: 1006-1013.

Treiman, M., W. Weber, and M. Gratzl (1983) Cyclic adenosine monophosphate and $\mathrm{Ca}^{2+}$ calmodulin dependent endogenous phosphorylation activity in membranes of bovine chromaffin secretory vesicles: Identification of two phosphorylated components of tyrosine hydroxylase and protein kinase regulatory subunit II. J. Neurochem. 40: 661-669.

Walicke, P. A., and P. H. Patterson (1981) The role of cyclic nucleotides in the transmitter choice made by cultured sympathetic neurons. J. Neurosci. 1: 333-342.

Wolinsky, E., and P. H. Patterson (1983) Tyrosine hydroxylase activity decreases with induction of cholinergic properties in cultured sympathetic neurons. J. Neurosci. 3: 1495-1500.

Wong, S. K.-F., B. R. Martin, and A. M. Tolkovsky (1985) Pertussis toxin substrate is a GDP $\beta \mathrm{S}, \mathrm{Mg}^{2+}$, methylmaleimide and temperature sensitive protein. Biochem. J. 232: 191-197.

Wray, W., T. Boulikas, V. P. Wray, and R. Hancock (1981) Silver staining of proteins in polyacrylamide gels. Anal. Biochem. 118: 197203. 